\title{
EKSISTENSI SHINTO DALAM SHOGATSU
}

\author{
Ratna Handayani ${ }^{1}$; Felicia ${ }^{2}$; Sonya Munadir Syah ${ }^{3}$ \\ 1,2,3 Japanese Department, Faculty of Language and Culture, Bina Nusantara University, \\ Jln. Kemanggisan Ilir III No. 45, Kemanggisan/Palmerah, Jakarta Barat 11480, \\ ratnahandayani@binus.edu@binus.edu
}

\begin{abstract}
Shinto as one of traditional beliefs of Japanese people unconsciously gives much influence in the cultural activities of Japanese people. Therefore, the authors had examined the existence of Shinto in Shogatsu by distributing questionnaires to the 20 respondents of Osaka University students. The article clarifies the intensity level and purpose of Japanese people in carrying out Shogatsu, in relation to the Shinto as a traditional belief of Japanese people. By use of the library research, analytical descriptive, and questionnaire method, it can be concluded that the majority of Japanese people do the activity of Shogatsu as a custom or tradition, without understanding the real purpose of Shogatsu. Actually, Shogatsu is highly associated to Shinto elements in it.
\end{abstract}

Keywords: Shinto, Shogatsu, tradition

\begin{abstract}
ABSTRAK
Shinto sebagai salah satu kepercayaan tradisional masyarakat Jepang, tanpa disadari banyak berpengaruh dalam kegiatan kebudayaan masyarakat Jepang. Oleh karena itu, penulis telah meneliti keberadaan Shinto dalam Shogatsu melalui angket yang disebarkan pada 20 responden mahasiswa Osaka University. Artikel ini menjelaskan tingkat intensitas dan tujuan masyarakat Jepang melakukan kegiatan dalam Shogatsu, sehubungan dengan keberadaan Shinto sebagai kepercayaan tradisional masyarakat Jepang. Dengan menggunakan metode penelitian kepustakaan, deskriptif analisis, dan angket, dapat disimpulkan bahwa sebagian besar masyarakat Jepang melakukan kegiatan Shogatsu sebagai kebiasaan atau tradisi, tanpa memahami tujuan kegiatan Shogatsu yang sesungguhnya. Sebenarnya Shogatsu sangat berkaitan dengan unsur Shinto di dalamnya.
\end{abstract}

Kata kunci: Shinto, Shogatsu, tradisi 


\section{PENDAHULUAN}

Untuk menguasai suatu bahasa tidaklah cukup hanya dengan mempelajari bahasanya saja, melainkan perlu ditunjang dengan mempelajari budaya negara pengguna bahasa tersebut. Ketika Bonvillain (2003) membicarakan makna dan pemakaian bahasa, ia menekankan bahwa bahasa mengandung makna dan maksud dari si pembicara, yang dapat diketahui dari budaya dan bahasa. Pentingnya keterkaitan peran budaya dalam pemakaian bahasa ini dikatakannya bahwa bahasa diperkaya fungsinya dari orang yang menggunakannya. Fungsi bahasa dan makna yang disampaikan adalah situasi, sosial, dan budaya.

Shinto sebagai salah satu kepercayaan tradisional masyarakat Jepang, tanpa mereka sadari banyak berpengaruh dalam kegiatan yang merupakan kebudayaan masyarakat Jepang. Berkenaan dengan itu, kami akan meneliti studi eksistensi Shinto sebagai kepercayaan tradisional Jepang yang diterapkan pada salah satu kebudayaan Jepang, yang tiap tahun dilakukan oleh masyarakat Jepang, yakni Shogatsu. Responden penelitian ini adalah mahasiswa Osaka University.

Di Jepang, mayoritas masyarakatnya menganut agama Buddha dan Shinto. Setelah itu, mayoritas terbanyak adalah Kristen yang mulai berkembang pesat. Di antaranya ada pula orang yang menganut 2 agama sekaligus. Menganut salah satu agama memang dianggap tidak begitu penting oleh masyarakat Jepang. Pada umumnya, orang Jepang tidak tahu ajaran agama dan tidak punya minat pada ajarannya. Datang ke kuil atau melakukan suatu ritual dan perayaan bagi orang Jepang sendiri itu semua merupakan kebiasaan, bukan merupakan kegiatan agama (Ishizawa, 2005).

Shinto merupakan kepercayaan pribumi Jepang, yang bermula pada sejarah kuno dan mitos pada masyarakat Jepang. Kegiatan peribadatan mengutamakan pemujaan terhadap arwah nenek moyang dan alam lingkungan. Sebagai agama asli bangsa Jepang, Shinto telah memberikan banyak pengaruh di dalam kehidupan masyarakat dan kebudayaan Jepang (Akasaka, 1989:113).

Arti kata Shinto yang paling mendasar adalah kepercayaan religius, yang ditemukan pada adat setempat dan diwariskan secara turun temurun di Jepang, termasuk juga di dalamnya kepercayaan pada hal gaib (Tsuda, 1965:10). Di dalam Shinto tidak ada doktrin ataupun kitab suci, namun kepercayaan ditunjukkan dengan perayaan. Sebelum adanya kuil Shinto (jinja), rakyat biasanya mendatangi berbagai tempat alam untuk memuja kami. Pada salah satu tempat tertentu, mereka berkumpul pada hari tertentu, mengundang datang dewa, dan mengungkapkan rasa terima kasih dengan memberikan persembahan (Inohana dan Edizal, 2002:95).

Shogatsu adalah sebuah perayaan tahun baru di Jepang dan merupakan salah satu kegiatan tahunan terpenting bagi masyarakat Jepang. Perayaan shogatsu tidak hanya sehari, tapi dirayakan selama 3 hingga 7 hari pertama bulan Januari. Meskipun begitu, perayaan utamanya tetap terpusat pada tanggal 1 Januari. Shogatsu juga sering disebut dengan oshogatsu, untuk bahasa lebih sopannya (Sudjianto, 2002:101).

Menurut Story of Shogatsu and 'Koh Hajime' dalam Nippon Kodo (2007), bagi masyarakat Jepang shogatsu memiliki makna sebagai semangat baru di permulaan tahun yang baru. Tenaga yang telah terkuras di tahun kemarin akan terisi dan segar kembali di awal tahun yang baru. Semua orang merayakan tahun baru dengan gembira dan juga berdoa semoga di tahun yang akan datang akan terus hidup dalam damai dan dilimpahi segala kebaikan.

Tujuan perayaan shogatsu untuk menyambut datangnya sang dewa terhormat, yang biasa disebut oleh masyarakat Jepang dengan toshigamisama. Yang dimaksud dengan toshigami adalah kami yang turun ke dunia pada saat tahun baru, dengan tujuan untuk menghidupkan kembali energi bumi (dunia). Semua persiapan yang dilakukan menjelang shogatsu ditujukan untuk toshigami 
tersebut. Sebutan untuk toshigami kini juga ditujukan kepada arwah para leluhur keluarga. Oleh karena itu, perayaan shogatsu juga merupakan salah satu bentuk penghormatan kepada arwah para leluhur (Brandon dan Stephan, 1994:17).

Tujuan jangka panjang penelitian ini adalah memberikan pemahaman yang mendalam tentang kebudayaan Jepang, yang nantinya dapat berguna dalam pemakaian bahasa Jepang, khususnya bagi mahasiswa sastra Jepang Universitas Bina Nusantara. Tujuan jangka pendek penelitian ini adalah memberikan pemahaman yang mendalam tentang budaya Jepang, khususnya tentang eksistensi Shinto dalam Shogatsu melalui hasil angket, dan memahami terdapatnya unsur-unsur Shinto pada Shogatsu, serta dapat memperkaya materi mata kuliah Masyarakat dan Kebudayaan Jepang.

\section{Metode Penelitian}

Metode penelitian yang digunakan adalah studi kepustakaan dan deskriptif analisis. Selain itu, digunakan juga metode angket untuk mendapatkan data tentang pandangan masyarakat Jepang terhadap keberadaan Shinto dalam Shogatsu. Studi literatur dilakukan dengan mengumpulkan data dari perpustakaan Universitas Bina Nusantara dan Japan Foundation, serta mencari data dengan menggunakan internet. Setelah data kepustakaan terkumpul, dilanjutkan dengan metode deskriptif analisis dan angket. Teknik angket digunakan untuk mendapatkan informasi yang benar dari subjek penelitian, dengan memperhatikan ruang lingkup penelitian.

Bentuk pertanyaan dalam angket bersifat tertutup, yakni responden diberi pilihan untuk menjawab pertanyaan sesuai dengan pendapat dan pandangan pribadinya. Angket disebarkan kepada 20 orang responden, yakni remaja Jepang, khususnya mahasiswa Jepang dari universitas di Jepang. Cara penyebaran angket menggunakan teknik angket tidak langsung, yakni peneliti mengirim angket kepada mahasiswa Jepang tanpa bertemu langsung dengan responden dan responden mengirim kembali angket yang sudah dijawab tersebut. Hasil data angket berasal dari angket yang telah disebar secara tidak langsung kepada 20 responden, yang kemudian dikembalikan oleh 17 responden.

\section{PEMBAHASAN}

\section{Gambaran Singkat Hasil dari Data Angket}

Hasil dari data angket tersebut terdiri dari 2 macam, yakni hasil angket tingkat partisipasi responden terhadap 12 macam kegiatan pada shogatsu dan hasil angket berdasarkan tujuan responden melakukan tiap jenis kegiatan pada shogatsu, yakni: oosouji, mochitsuki, memajang kadomatsu, memasang shimenawa, memasang shimekazari, memajang kagamimochi, makan kagamimochi bersama-sama setelah perayaan tahun baru, memajang gohei atau shide, memajang sakaki, melakukan hatsumode, melakukan norito di otera, serta melakukan shinsen di otera.

\section{Analisis Konsep Shinto dalam Melakukan Kegiatan Shogatsu}

Shogatsu merupakan perayaan tahun baru di Jepang yang biasa dirayakan oleh seluruh rakyat Jepang. Dalam shougatsu biasanya terdapat 12 jenis kegiatan yang dilakukan menjelang tahun baru, pada hari tahun baru, dan setelah perayaan tahun baru selesai. Dari data angket, dapat diketahui alasan responden melakukan kegiatan shogatsu, baik karena memahami tujuan kegiatan dalam shogatsu tersebut dilakukan, maupun karena kebiasaan atau karena alasan kesenangan atau keindahan. Berikut ini kami akan menganalisis terdapatnya konsep Shinto, khususnya pada unsur-unsur Shinto, dalam tujuan responden melakukan tiap kegiatan shogatsu dari 12 kegiatan yang ada. Namun, sebelumnya akan kami jelaskan terlebih dulu hasil data angket mengenai tingkat partisipasi responden terhadap tiap kegiatan tersebut. 


\section{Analisis Unsur Shinto dalam Melakukan Kegiatan Oosouji pada Shogatsu}

Sebelum menganalisis data angket tujuan responden melakukan kegiatan oosouji, kami akan menjelaskan tingkat partisipasi responden melakukan kegiatan oosouji pada shogatsu.

Berdasarkan data angket tingkat partisipasi responden terhadap pelaksanaan oosouji, menunjukkan bahwa 6 persen responden tidak penah melakukan oosouji, tidak ada responden yang jarang sekali atau kadang-kadang melakukan ousouji, selebihnya yakni 94 persen responden melakukan kegiatan oosouji dengan tingkat intensitas yang berbeda-beda. Berdasarkan data tersebut menunjukkan cukup tinggi jumlah responden yang melakukan kegiatan oosouji menjelang shogatsu.

Pada pertanyaan angket nomor 1, "Mengapa anda melakukan oosouji secara besar-besaran sebelum hari shogatsu?.” Responden yang memilih jawaban a. Karena tradisi atau kebiasaan, sebanyak 76 persen. Sementara itu, tidak ada yang memilih jawaban b. Karena menyenangkan, maupun memilih c. Untuk menyambut toshigami. Sedangkan responden yang tidak melakukan kegiatan oosouji tidak diperkenankan menjawab pertanyaan angket nomor 1 tersebut.

Untuk mengetahui jawaban yang tepat dari pertanyaan angket tersebut, responden harus memahami arti oosouji terlebih dulu. Menurut Sudjianto (2002:81), oosouji adalah kegiatan pembersihan secara besar-besaran yang dilakukan menjelang shogatsu. Oosuji tidak hanya dilakukan di rumah-rumah, tapi juga di kuil, gedung sekolah, perkantoran, dan tempat lain. Kegiatan pembersihan yang dilakukan yaitu meliputi menyapu, mengepel, serta mengelap seisi rumah untuk menghilangkan seluruh debu dan kotoran yang ada. Biasanya semua orang ikut terlibat dalam kegiatan ini.

Mengenai tujuan dilakukannya oosouji, Brandon (1994:17) mengatakan bahwa, tujuan dari oosouji adalah untuk menyambut datangnya sang dewa terhormat, yang biasa disebut oleh masyarakat Jepang dengan toshigamisama. Mereka meyakini bahwa sang toshigami hanya mau mendatangi rumah-rumah atau tempat-tempat yang dalam keadaan bersih.

Berkaitan dengan tujuan dilakukannya kegiatan oosouji pada Shogatsu, menurut analisis kami, terdapat konsep Shinto dalam kegiatan oosouji, yakni terdapatnya unsur penyucian (harai) dalam konsep Shinto pada kegiatan oosouji. Hal ini sesuai dengan yang dikatakan oleh Robinson (2006), bahwa di dalam Shinto terdapat 4 penegasan dalam jiwa Shinto dan salah satunya adalah kebersihan fisik. Kebersihan fisik berkaitan dengan penyucian. Dalam konsep ini ditegaskan bahwa kebersihan adalah unsur yang penting dalam Shinto. Kondisi kita harus dalam keadaan bersih atau suci bila ingin bertemu kami, misalnya saat mengunjungi kuil. Demikian pula dengan oosouji, masyarakat meyakini bahwa keadaan rumah harus bersih bila ingin dikunjungi oleh kami tersebut.

Berdasarkan analisis di atas, jawaban yang tepat dari pertanyaan angket nomor 1 adalah c. Untuk menyambut toshigami. Sementara itu, tidak ada responden yang menjawab dengan benar.

\section{Analisis Melakukan Kegiatan Mochitsuki pada Shogatsu}

Berdasarkan data angket tingkat partisipasi responden melakukan kegiatan mochitsuki pada Shogatsu, 12 persen responden tidak pernah melakukan kegiatan mochitsuki, selebihnya yakni 88 persen melakukan kegiatan mochitsuki, dengan tingkat intensitas yang berbeda-beda.

Pada pertanyaan angket nomor 2, "Mengapa anda mengikuti kegiatan mochitsuki beberapa hari menjelang shogatsu?.” Responden yang memilih jawaban a. Karena tradisi atau kebiasaan, sebanyak 53 persen, dan yang memilih jawaban b. Karena menyenangkan, sebanyak 24 persen. Sementara itu, tidak ada yang memilih jawaban c. Untuk persembahanan kepada Kami sebagai rasa syukur. Sedangkan responden yang tidak melakukan kegiatan mochitsuki, tidak diperkenankan menjawab pertanyaan angket nomor 2 tersebut. 
Untuk mengetahui jawaban yang tepat, responden harus memahami lebih bulu makna mochitsuki. Mochitsuki, menurut Sudjianto (2002:65-66) merupakan kegiatan membuat mochi (kue beras) secara tradisional, yang dilakukan 3 hari menjelang tahun baru. Bahan dasarnya menggunakan beras khusus yang disebut dengan mochigome.

Menurut analisis kami, dalam kegiatan mochitsuki terdapat konsep Shinto di dalamnya, yakni terdapat unsur persembahan (shinsen) dalam Shinto. Hal ini dikarenakan mochi yang dihasilkan dari kegiatan mochitsuki, sebagian dipersembahkan kepada kami. Makna dari mochitsuki adalah ungkapan rasa syukur manusia kepada kami. Dengan menumbuk padi dengan usu dan kine, serta memberikan hasil dari mochitsuki tersebut kepada kami, maka manusia dapat mengekspresikan wujud rasa terima kasih mereka kepada kami yang telah memberkati mereka sepanjang tahun. Menurut analisis kami, mochi memiliki kaitan erat dengan unsur persembahan dalam Shinto karena mochi selalu digunakan di berbagai ritual Shinto sebagai persembahan kepada kami. Hal tersebut sesuai dengan pendapat Ono (1992:54), yang mengatakan bahwa beras dipersembahkan di banyak kesempatan dalam perayaan dan ritual-ritual Shinto, baik dalam bentuk beras, maupun sesudah diolah menjadi kue beras yang dikenal dengan mochi. Beras merupakan persembahan dan pujian kepada dewa di Jepang.

Berdasarkan analisis di atas, untuk pertanyaan angket nomor 2, "Mengapa anda mengikuti kegiatan mochitsuki beberapa hari menjelang Shogatsu?.” Maka jawaban yang tepat adalah c. Untuk persembahan kepada kami sebagai rasa syukur. Sementara itu, tidak ada responden yang menjawab dengan tepat.

\section{Analisis Melakukan Kegiatan Memajang Kadomatsu di Rumah pada Shogatsu}

Berdasarkan data angket tingkat partisipasi responden terhadap kegiatan memajang kadomatsu di rumah, terlihat hanya 7 persen responden yang tidak pernah memajang kadomatsu, selebihnya yakni 93 persen memajang dengan tingkat intensitas yang berbeda-beda.

Pada pertanyaan angket nomor 3, "Mengapa anda memajang kadomatsu di rumah anda pada shogatsu?.” Berdasarkan data angket, terdapat 4 persen responden yang menjawab a. Karena tradisi/ kebiasaan, sejumlah 1 persen responden menjawab b. Supaya terlihat indah, sementara tidak ada responden yang menjawab c. Sebagai penunjuk jalan bagi kami untuk datang berkunjung. Responden yang tidak memajang kadomatsu pada shogatsu tidak diperkenankan menjawab peranyaan nomor 3 tersebut.

Kadomatsu menurut Brandon dan Stephan (1994:64), adalah dekorasi tradisional shogatsu yang terbuat dari rangkaian bambu, batang pohon cemara, dan ranting pohon plum, yang biasanya diletakkan di depan serambi atau pintu rumah. Selain itu, juga dipasang di depan pertokoan, sekolah, maupun perkantoran.

Menurut analisis kami, kadomatsu berfungsi untuk mengundang, menjemput, atau menyambut datangnya kami atau arwah para leluhur. Hal ini sesuai dengan Sakurai (1991:40-42), bahwa penggunaan tumbuhan hijau merupakan hal yang vital dalam Shinto karena tumbuhan hijau tersebut akan menjadi tanda atau penunjuk jalan bagi kami untuk datang berkunjung. Selain berfungsi sebagai penunjuk jalan untuk kami, kadomatsu juga memiliki fungsi untuk mencegah masuknya unsur-unsur negatif atau roh-roh jahat. Menurut Sakurai (1991:40-42), bambu dan cemara juga digunakan dalam Shinto sebagai simbol penyucian. Hanya dengan meletakkan bambu atau tumbuhan cemara di suatu tempat tertentu, menandakan bahwa tempat tersebut telah disucikan. Oleh karena itu, menurut analisis kami, terdapat konsep Shinto, yakni terdapatnya unsur penyucian (harai) dalam kegiatan memajang kadomatsu pada Shogatsu. 
Berdasarkan analisis di atas, jawaban yang tepat untuk pertanyaan angket nomor 3, ”Mengapa anda memajang kadomatsu di rumah anda pada Shogatsu", adalah jawaban c. Sebagai petunjuk jalan bagi kami untuk datang berkunjung. Sementara itu, tidak ada responden yang menjawab dengan tepat.

\section{Analisis Memasang Shimenawa di Rumah pada Shogatsu}

Berdasarkan data angket tingkat partisipasi responden melakukan kegiatan memasang shimenawa di rumah, memperlihatkan 41 persen responden tidak pernah memasang shimenawa, selebihnya, yakni 59 persen mengikuti kegiatan tsb dengan tingkat intensitas yang berbeda-beda.

Pada pertanyaan angket nomor 4, "Mengapa anda memasang shimenawa di rumah anda pada Shogatsu." Terdapat 8 persen responden yang menjawab a. Karena tradisi atau kebiasaan, 1 persen responden yang menjawab b. Supaya terlihat indah, dan tidak ada responden yang menjawab c. Untuk melindungi hal-hal negatif dan roh-roh jahat. Responden yang tidak memasang shimenawa pada shogatsu, tidak diperkenankan menjawab angket pertanyaan nomor 4 tersebut.

Shimenawa「注連縄」 merupakan tali atau tambang yang terbuat dari jerami yang dijalin hingga membentuk hiasan, yang digantung secara melintang di depan gerbang atau pintu masuk. Pada shimenawa biasanya sering ditambahkan shide, yaitu kertas berbentuk zig-zag yang sering digunakan dalam ritual Shinto. Shimenawa dipercaya dapat melindungi dari hal-hal negatif atau ketercemaran. (Brandon dan Stephan, 1994 : 51).

Menurut analisis kami, terdapat konsep Shinto dalam kegiatan memasang shimenawa di rumah pada Shogatsu, yakni terdapatnya unsur penyucian (harai) dalam kegiatan tersebut. Menurut Sakurai (1991: 42), di dalam Shinto ada beberapa benda yang dipercaya dapat menyucikan serta melindungi dari ketercemaran dan roh-roh jahat atau hal-hal negatif lainnya, seperti bambu, shimenawa, tumbuhan sakaki, dan cemara. Dengan menaruh benda-benda tersebut di suatu tempat, menandakan bahwa tempat tersebut telah disucikan. Shimenawa sering digunakan di kuil-kuil Shinto untuk mencegah masuknya roh jahat.

Berdasarkan analisis di atas, maka jawaban yang tepat untuk pertanyaan angket no. 4 Mengapa anda memasang shimenawa di rumah anda pada Shogatsu, adalah jawaban c. Untuk melindungi dari hal-hal negatif dan roh-roh jahat. Sementara tidak ada responden yang menjawab pertanyaan angket nomor 4 tersebut dengan tepat.

\section{Analisis Memasang Shimekazari di Rumah pada Shogatsu}

Berdasarkan data angket tingkat partisipasi responden melakukan kegiatan memasang shimekazari di rumah, terdapat 2 persen responden tidak pernah memasang shimekazari, selebihnya, yakni 71 persen mengikuti kegiatan tersebut dengan tingkat intensitas yang berbeda-beda. Pada pertanyaan angket nomor 5, "Mengapa anda memasang shimekazari di rumah anda pada Shogatsu.”. Terdapat 10 persen responden yang menjawab a. Karena tradisi/ kebiasaan, 1 persen responden yang menjawab b. supaya terlihat indah dan tidak ada responden yang menjawab c. Untuk melindungi dari hal-hal negatif dan roh-roh jahat. Sedangkan responden yang tidak melakukan kegiatan memasang shimekazari, tidak diperkenankan menjawab pertanyaan angket nomor 5 ini.

Shimekazari merupakan hiasan yang terbuat dari rangkaian shimenawa, yakni tali atau tambang dari jerami yang dijalin hingga membentuk hiasan yang digantung secara melintang di depan gerbang atau pintu masuk dan biasanya sering ditambahkan shide, yaitu kertas berbentuk zigzag dan sering digunakan dalam ritual Shinto, serta ditambahkan pula ornamen khusus lainnya dan biasa dipasang di depan pintu masuk. Fungsi shimekazari adalah menangkal masuknya roh jahat dan juga melambangkan sebuah keberuntungan (Sudjianto, 2002:97). 
Tiga buah ornamen yang paling umum pada shimekazari adalah daidai (jeruk masam), daun yuzuriha, dan daun urajiro. Daidai memiliki arti "dari generasi ke generasi”, semacam hubungan antara orang tua dan anak. Daun yuzuriha memiliki makna dapat memperkuat hubungan antara ayah dan anak. Sedangkan daun urajiro memiliki makna sebagai keharmonisan hubungan antara suami dan istri (Stephan, 1994:55).

Menurut analisis kami, terdapat konsep Shinto pada hiasan shimekazari, yakni terdapatnya unsur penyucian (harai) dalam Shinto. Pada shimekazari menggunakan bahan utama shimenawa, yakni tali jerami yang dijalin hingga membentuk hiasan yang digantung melintang, yang di dalam Shinto digunakan untuk melindungi dari ketercemaran, sama halnya dengan fungsi shimekazari. Shimekazari juga digunakan untuk menyambut datangnya toshigamisama, sehingga shimekazari juga harus terlihat hijau dan segar seperti halnya kadomatsu, dengan menambahkan tumbuhan hijau, yakni daun urajiro dan daun yuzuriha. Selain itu, pada shimekazari juga sering ditambahkan shide, yang sering digunakan dalam ritual penyucian Shinto. Seperti yang dikatakan oleh Takemoto (2006), bahwa kertas putih juga sering digunakan dalam ritual Shinto sebagai simbol penyucian, seperti halnya shide (kertas berbentuk zig-zag) yang sering digunakan dalam berbagai ritual Shinto. Oleh karena itu, menurut analisis kami, pada hiasan shimekazari terdapat konsep Shinto, yakni terdapat unsur penyucian (harai).

Berdasarkan analisis di atas, untuk pertanyaan nomor 5, "Mengapa anda memajang kagamimochi di rumah anda pada Shogatsu?.” Jawaban yang tepat adalah c. Untuk melindungi dari hal-hal negatif dan roh-roh jahat. Sementara itu, tidak ada responden yang menjawab dengan tepat.

\section{Analisis Memajang Kagamimochi di Rumah pada Shogatsu}

Berdasarkan data angket tingkat partisipasi responden melakukan kegiatan memajang kagamimochi di rumah, terdapat 24 persen responden tidak pernah melakukan kegiatan memajang kagamimochi, selebihnya yakni 76 persen mengikuti kegiatan tersebut dengan tingkat intensitas yang berbeda-beda.

Pada pertanyaan angket nomor 6, "Mengapa anda memajang kagamimochi di rumah anda pada Shogatsu.” Terdapat 53 persen responden yang menjawab a. Karena tradisi/ kebiasaan, 6 persen responden yang menjawab b. supaya terlihat indah dan 12 persen responden yang menjawab c. Untuk persembahan kepada kami. Sedangkan responden yang tidak melakukan kegiatan memajang kagamimochi, tidak diperkenankan menjawab pertanyaan angket nomor 6 ini.

Kagamimochi 「鏡餅」 adalah dekorasi khas shogatsu yang terbuat dari mochi berbentuk bundar pipih, yang diletakkan bertingkat dengan ukuran terbesar di bawah dan terkecil di atas. Mochi ini disebut kagamimochi karena bentuknya yang menyerupai cermin. Dalam bahasa Jepang, kagami berarti cermin (Sakurai, 1991:46). Kagamimochi「鏡䭝」 merupakan makanan yang ditujukan kepada kami dan diletakkan di tempat-tempat tertentu yang diperkirakan kami akan hadir, seperti di dapur, ruang tengah atau pada kamidana. Dekorasi ini menyimbolkan banyak hal, di antaranya adalah tahun yang datang dan pergi.

Menurut analisis kami, terdapat konsep Shinto pada kegiatan memajang kagamimochi ini, yakni adanya unsur persembahan (shinsen) dalam Shinto, yang salah satu bentuknya adalah makanan. Kagamimochi digunakan sebagai persembahan khusus yang ditujukan untuk kami. Kami merupakan roh spiritual suci yang dipuja dalam Shinto dan mochi merupakan persembahan yang paling umum diberikan pada kami dalam berbagai perayaan dan ritual Shinto. Hal tersebut sesuai dengan Ono (1992:54), bahwa beras dipersembahkan di banyak kesempatan dalam perayaan dan ritual-ritual Shinto, baik dalam bentuk beras, maupun sesudah diolah menjadi kue beras yang dikenal dengan mochi. Beras merupakan persembahan dan pujian kepada dewa di Jepang. 
Bentuk mochi yang bundar pipih seperti cermin, merupakan suatu hal yang sangat penting dalam Shinto. Dahulu, cermin sering digunakan sebagai pesembahan yang khusus diberikan kepada sang Dewi Matahari, yang disebut dengan Amaterasu o Mikami, sehingga cermin merupakan salah satu benda yang dianggap suci dalam Shinto. Hal tersebut sesuai dengan Kato (1971:22), yang mengatakan bahwa dalam ajaran Shinto ada beberapa benda yang dianggap suci seperti pedang, cermin, dan permata. Tiga benda ini umumnya diletakkan di altar Shinto (kamidana) sebagai persembahan pada kami. Cermin dan permata merupakan benda milik Amaterasu (Dewi Matahari).

Berdasarkan analisis di atas, untuk pertanyaan angket nomor 6, ”Mengapa anda memajang kagamimochi di rumah anda pada Shogatsu?.” Maka jawaban yang tepat adalah c. Untuk persembahan kepada kami. Terdapat 12 persen responden yang menjawab dengan tepat.

\section{Analisis Melakukan Kegiatan Makan Kagamimochi Bersama setelah Perayaan Shogatsu Selesai}

Berdasarkan data partisipasi responden dalam kegiatan makan kagamimochi bersama setelah perayaan Shogatsu selesai, terdapat 35 persen responden tidak pernah melakukan kegiatan tersebut, selebihnya terdapat 65 persen responden yang melakukan kegiatan makan kagamimochi bersama setelah perayaan Shogatsu selesai, dengan tingkat intensitas yang berbeda-beda.

Pada angket nomor 7, “Apa tujuan khusus anda turut makan kagamimochi yang dipotong untuk dimakan bersama setelah perayaan tahun baru selesai?.” Terdapat 53 persen responden yang menjawab a. Karena tradisi/kebiasaan. Sementara itu, tidak ada responden yang menjawab b. Mempererat kebersamaan, dan 6 persen responden yang menjawab c. Mempercayai akan mendapat kekuatan kami dari mochi tersebut. Bagi responden yang tidak melakukan kegiatan tersebut, tidak diperkenankan menjawab pertanyaan nomor 7 ini.

Seperti yang telah dijelaskan sebelumnya, mengenai makna kagamimochi 「鏡餅」 adalah dekorasi khas shogatsu yakni mochi berbentuk bundar pipih, yang disusun bertingkat dengan ukuran terbesar di bawah dan terkecil di atas. Mochi ini disebut sebagai kagamimochi karena bentuknya yang menyerupai cermin. Dalam bahasa Jepang, kagami berarti cermin (Sakurai, 1991:46).

Kagamimochi dipercaya mengandung kekuatan kami di dalamnya. Oleh karena itu, juga sering disebut dengan chikaramochi, yang berarti "mochi kekuatan". Setelah perayaan tahun baru selesai, mochi tersebut dipotong untuk dimakan bersama-sama oleh seluruh anggota keluarga, karena dipercaya orang yang memakan mochi tersebut akan mendapatkan kekuatan kami dari chikaramochi tersebut.

Menurut analisis kami, terdapat konsep Shinto dalam kegiatan makan kagamimochi bersama ini, yakni terdapatnya unsur yang keempat dalam Shinto, yang disebut naorai. Menurut Ono (1992:57), naorai merupakan pesta jamuan sakral atau suci setelah perayaan atau upacara Shinto. Naorai berarti "makan bersama-sama dengan kami”. Dahulu di Jepang, pada saat perayaan panen, terdapat kepercayaan bila kita memakan beras yang baru panen bersama kami, maka kita akan mendapatkan kekuatan kami. Seperti yang dikatakan oleh Inohana dan Edizal (2002:96), bahwa dengan memakan beras baru pada perayaan panen padi bersama kami, mereka percaya dapat bersatu dengan jiwa kami dan memperoleh tenaga gaib dari kami. Hal ini sama dengan kagamimochi yang dipercaya dapat memberikan kekuatan kami apabila memakannya.

Berdasarkan analisis di atas, untuk pertanyaan angket nomor 7, “Apa tujuan khusus anda turut makan kagamimochi yang dipotong untuk dimakan bersama, setelah perayaan tahun baru selesai”, maka jawaban yang tepat adalah c. Mempercayai akan mendapat kekuatan kami dari mochi tersebut. Berdasarkan angket tersebut, hanya 6 persen responden yang menjawab dengan tepat. Sementara itu, sebagian besar menjawab a. Karena tradisi/ kebiasaan. 


\section{Analisis Memajang Gohei atau Shide di Rumah pada Shogatsu}

Berdasarkan data angket tingkat partisipasi responden terhadap kegiatan memajang gohei atau shide di rumah, terdapat 58 persen responden tidak pernah melakukan kegiatan memajang gohei atau shide di rumah, sedangkan selebihnya yakni 42 persen responden memasang gohei atau shide di rumah dengan tingkat intensitas yang berbeda-beda.

Berdasarkan data angket pada pertanyaan nomor 8, "Mengapa anda memajang gohei atau shide di rumah anda pada Shogatsu?.” Terdapat 29 persen responden yang menjawab a. Karena tradisi/kebiasaan, tidak ada responden yang menjawab b. Supaya terlihat indah, dan 12 persen responden yang menjawab c. Untuk persembahan kepada kami. Sementara itu, responden yang tidak melakukan kegiatan memajang gohei atau shide tidak diperkenankan menjawab pertanyaan angket nomor 8 ini.

Untuk mengetahui jawaban yang tepat dari pertanyaan angket tersebut, perlu memahami terlebih dulu arti gohei dan shide. Gohei [御幣] merupakan dekorasi altar yang berupa 2 buah shide yang ditempel pada sebatang kayu atau bambu dan diletakkan di toshidana (altar khusus yang dipersiapkan untuk menyambut datangnya toshigami) pada saat shogatsu. Selain itu, gohei juga diletakkan di tempat lain seperti di dapur dan tempat-tempat lainnya, yang diperkirakan kami akan hadir di tempat tersebut. Gohei juga merupakan salah satu bentuk persembahan yang ditujukan kepada toshigamisama. Berbeda dengan dekorasi shogatsu lainnya yang disimpan kembali setelah perayaan selesai, gohei tetap dibiarkan terpajang di tempatnya sepanjang tahun, namun selalu diganti atau diperbarui saat akhir tahun (Brandon dan Stephan, 1994:76).

Menurut analisis kami, terdapat konsep Shinto pada fungsi hiasan gohei, yakni terdapatnya unsur persembahan dalam Shinto yang disebut dengan shinsen. Dalam hal ini, gohei sering dipakai dalam ritual Shinto sebagai persembahan pada kami, dengan meletakkannya pada toshidana, yang merupakan altar untuk menaruh persembahan kepada kami pada saat shogatsu. Hal tersebut sesuai dengan Ono (1992:55), bahwa gohei juga merupakan salah satu persembahan bagi kami, yang terbuat dari 2 buah shide yang ditempel pada sebuah tangkai kayu atau bambu. Pada saat shogatsu, gohei juga merupakan salah satu bentuk persembahan bagi sang toshigami.

Berdasarkan analisis di atas, maka untuk pertanyaan angket nomor 8, Mengapa anda memajang gohei atau shide di rumah pada Shogatsu?.” Jawaban yang tepat adalah c. Untuk persembahan kepada kami, yang dijawab oleh 12 persen responden.

\section{Analisis Memajang Sakaki di Rumah pada Shogatsu}

Berdasarkan data angket tingkat partisipasi responden melakukan kegiatan memajang sakaki di rumah pada Shogatsu, terdapat 46 persen responden tidak pernah melakukan kegiatan itu, selebihnya adalah 54 persen responden melakukan kegiatan memajang sakaki di rumah pada Shogatsu dengan tingkat intensitas yang berbeda-beda.

Pada pertanyaan angket nomor 9, "Mengapa anda memajang sakaki di rumah pada Shogatsu?.” Terdapat 35 persen responden yang menjawab a. Karena tradisi/kebiasaan. Sementara itu, tidak ada responden yang menjawab b. Supaya terlihat indah dan 12 persen responden yang menjawab c. Untuk persembahan kepada kami. Responden yang tidak melakukan kegiatan memajang sakaki tidak diperkenankan menjawab pertanyaan nomor 9 ini.

Ranting tumbuhan sakaki「榊」 merupakan salah satu hiasan persembahan pada saat shogatsu yang diletakkan sepasang, di dalam vas bunga di atas altar khusus. Selain itu, ada juga sakaki yang digunakan untuk persembahan dengan menempelkan kertas putih pada sakaki, yang disebut dengan tamagushi「玉串」(Brandon dan Stephan, 1994:76). 
Menurut analisis kami, terdapat konsep Shinto pada fungsi ranting tumbuhan sakaki, yakni terdapatnya unsur persembahan (shinsen) dalam Shinto, karena ranting sakaki digunakan sebagai persembahan simbolis dalam Shinto pada Shogatsu. Hal tersebut sesuai dengan Ono (1992:55), bahwa persembahan simbolis biasanya adalah ranting tumbuhan sakaki yang sudah ditempeli dengan kertas putih, yang disebut dengan tamagushi. Selain itu, terdapatnya unsur penyucian (harae) dalam Shinto pada fungsi sakaki, karena sakaki juga merupakan tumbuhan suci yang sering digunakan sebagai media penyucian dalam Shinto. Dengan menaruh benda-benda tersebut di suatu tempat, menandakan bahwa tempat tersebut telah disucikan.

Berdasarkan analisis di atas, maka untuk pertanyaan angket nomor 9, "Mengapa anda memajang sakaku di rumah pada Shogatsu?.” Jawaban yang tepat adalah c. Untuk persembahan kepada kami, yang dijawab oleh 12 persen responden.

\section{Analisis Melakukan Kegiatan Hatsumode pada Shogatsu}

Berdasarkan data angket mengenai tingkat partisipasi responden dalam melakukan kegiatan hatsumode, terdapat 18 persen responden yang tidak pernah melakukan kegiatan hatsumode, selebihnya sebanyak 82 persen responden melakukan kegiatan hatsumode pada Shogatsu, dengan tingkat intensitas yang berbeda-beda.

Pada pertanyaan angket nomor 10, "Mengapa anda melakukan hatsumode pada Shogatsu?." Terdapat 35 persen responden yang menjawab a. Karena tradisi/kebiasaan. Sementara itu, tidak ada yang menjawab b. Karena menyenangkan dan 35 persen responden menjawab c. Untuk berdoa kepada kami. Bagi responden yang tidak pernah melakukan kegiatan hatsumode, tidak diperkenankan menjawab pertanyaan angket nomor 10 tersebut.

Kunjungan pertama ke kuil-kuil di tahun yang baru dikenal dengan istilah hatsumode「初詣 $」$. Perayaan shogatsu dirayakan selama 3 hingga 7 hari berturut-turut, namun puncak perayaannya pada tanggal 1 Januari.. Pada pagi hari pertama saat tahun baru, yang disebut dengan gantan「元旦」, umumnya orang-orang pergi ke kuil-kuil Shinto (jinja) ataupun ke kuil Buddha (otera) untuk memohon keberkahan kepada kami agar diberikan kehidupan yang baik, kesehatan, serta kemakmuran selama sepanjang tahun. Biasanya selama 3 hari berturut-turut, kuil akan dipenuhi oleh antrian orangorang yang datang berkunjung untuk berdoa (Brandon dan Stephan, 1994:109).

Menurut analisis kami, terdapat konsep Shinto dalam kegiatan hatsumode, (kunjungan ke kuilkuil yang biasanya dilakukan di hari pertama di tahun baru, yang bertujuan untuk berdoa kepada kami). Dalam konsep Shinto, terdapat unsur norito (permohonan) pada hatsumode tersebut. Pergi mengunjungi kuil dan berdoa merupakan salah satu bentuk ritual pemujaan dalam Shinto. Hal ini sesuai dengan Ono (1992:55-56 ), bahwa unsur yang ketiga dalam pemujaan Shinto adalah permohonan (norito). Yang dimaksud dengan norito yaitu upacara permohonan yang dilakukan di kuil.

Berdasarkan analisis di atas, untuk pertanyaan angket nomor 10, Mengapa anda melakukan kegiatan hatsumode pada Shogatsu?.” Maka jawabah yang tepat adalah c. Untuk berdoa kepada kami. Terdapat 35 persen responden yang menjawab pertanyaan nomor 10 tersebut dengan tepat.

\section{Analisis Melakukan Kegiatan Norito pada Shogatsu}

Berdasarkan data angket tingkat partisipasi responden melakukan kegiatan norito di jinja pada Shogatsu, terdapat 64 persen responden tidak pernah melakukan kegiatan norito di jinja pada Shogatsu, sisanya 36 persen responden melakukan kegiatan norito di jinja, dengan tingkat intensitas yang berbeda-beda. 
Pada pertanyaan angket nomor 11, "Mengapa anda melakukan norito di jinja pada Shogatsu?.” Terdapat 18 persen responden yang menjawab a. Karena tradisi/kebiasaan. Sementara itu, tidak ada responden yang menjawab b. Karena menyenangkan dan 6 persen responden menjawab c. Sebagai bentuk pemujaan dan memohon kepada kami. Sementara itu, responden yang tidak pernah melakukan kegiatan tersebut tidak diperkenankan menjawab pertanyaan angket nomor 11.

Yang dimaksud dengan norito adalah upacara permohonan yang dilakukan di kuil (jinja). Norito secara formalnya dipimpin oleh pendeta, namun juga dapat dilakukan secara individu. Salah satu bentuk norito adalah permohonan yang dilakukan di kuil (jinja) pada saat shogatsu tersebut. Orang-orang berdatangan ke kuil untuk melakukan permohonan kepada kami.

Menurut analsis kami, terdapat konsep Shinto dalam kegiatan norito di jinja (kuil), yakni terdapatnya unsur ketiga dalam Shinto, norito, yang berarti permohonan pada kegiatan norito dalam Shogatsu. Menurut Ono (1992:55-56), yang dimaksud dengan norito adalah upacara permohonan yang dilakukan di kuil. Berdasarkan analisis di atas, mengenai pertanyaan angket nomor 11, "Mengapa anda melakukan norito di jinja pada Shogatsu?.” Maka jawaban yang tepat adalah c. Sebagai bentuk pemujaan dan memohon kepada kami. Berdasarkan data angket, hanya 6 persen responden yang menjawab dengan tepat.

\section{Analisis Melakukan Kegiatan Melempar Koin di Jinja pada Shogatsu}

Berdasarkan data angket tingkat partisipasi responden melakukan kegiatan melempar koin di jinja, terdapat 12 persen responden tidak pernah melakukan kegiatan melempar koin di jinja pada saat Shogatsu. Untuk selebihnya, terdapat 88 persen responden yang melakukan kegiatan tersebut dengan tingkat intensitas yang berbeda-beda.

Pada pertanyaan angket nomor 12, "Mengapa anda melempar koin di jinja pada saat Shogatsu?.” Terdapat 41 persen responden yang menjawab a. Karena tradisi/ kebiasaan, 6 persen responden yang menjawab b. Karena menyenangkan, dan 29 persen responden yang menjawab c. Sebagai bentuk persembahan kepada kami. Bagi responden yang tidak pernah melakukan kegiatan melempar koin di jinja pada saat Shogatsu, tidak diperkenankan menjawab pertanyaan angket nomor 12 tersebut.

Di hari pertama tahun baru, orang-orang melakukan hatsumode, yakni pergi ke kuil untuk berdoa dan memohon kepada kami. Selain berdoa, mereka juga melemparkan koin ke dalam kotak suci yang terdapat di dalam kuil, sambil menepukkan tangan dua kali dan berdoa. Menurut analisis kami, terdapat konsep Shinto dalam kegiatan tersebut, yakni terdapatnya unsur persembahan (shinsen) dalam Shinto. Hal ini sesuai dengan pendapat Ono (1992:53), bahwa unsur kedua yang terpenting dalam pemujaan Shinto adalah persembahan (shinsen). Bentuk dari persembahan ini bisa dibedakan menjadi 4 jenis, yaitu berupa uang, makanan atau minuman, material (barang), dan benda simbolis. Persembahan berupa uang, yaitu dengan melempar koin ke dalam kotak suci. Bentuk lain dari persembahan uang adalah dengan mendonasikan uang kepada kuil untuk kepentingan kuil, serta keperluan perbaikan kuil.

Berdasarkan analisis di atas, untuk pertanyaan angket nomor 12, "Mengapa anda melempar koin di jinja pada saat Shogatsu?.” Maka jawabah yang tepat adalah c. Sebagai bentuk persembahan kepada kami. Sedangkan responden yang menjawab dengan tepat ada sebanyak 29 persen responden. 


\section{PENUTUP}

Sesuai dengan yang dikatakan oleh Ishizawa (2005), bahwa orang Jepang sendiri melakukan suatu ritual dan perayaan sebagai kebiasaan bukan sebagai pelaksanaan kegiatan agama. Hal ini juga dapat dilihat pada data hasil angket penelitian yang ditujukan pada mahasiswa Jepang, khususnya dari Osaka University. Berdasarkan data angket tersebut, dapat disimpulkan bahwa sebagian besar responden melakukan 12 kegiatan yang biasa dilakukan pada Shogatsu, meskipun dengan tingkat intensitas yang berbeda-beda.

Tujuan sebagian besar responden melakukan 12 kegiatan pada Shogatsu tersebut karena tradisi atau kebiasaan, serta sangat sedikit yang bertujuan melakukan kegiatan pada Shogatsu karena pemahaman responden tentang tujuan kegiatan pada Shogatsu yang memang berhubungan dengan konsep Shinto. Oleh karena itu, dapat diketahui berdasarkan data angket tersebut tentang fenomena responden, dalam hal ini mahasiswa Jepang, terhadap pemahaman eksistensi Shinto, khususnya unsurunsur Shinto dalam Shogatsu.

Berdasarkan pendapat para peneliti kepercayaan Shinto, dapat disimpulkan bahwa terdapatnya eksistensi Shinto, khususnya unsur-unsur Shinto, yakni penyucian (harai), persembahan (shinsen), permohonan (norito), dan pesta jamuan sakral setelah Shogatsu selesai (naorai), pada 12 buah kegiatan pada Shogatsu.

Berikut ini terdapatnya eksistensi Shinto, khususnya unsur-unsur Shinto dalam kegiatankegiatan pada Shogatsu. Pertama, terdapatnya eksistensi Shinto, khususnya unsur penyucian (harai) pada kegiatan: oosouji (pembersihan secara besar-besaran), memajang kadomatsu di rumah, memasang shimenawa di rumah, dan memasang shimekazari di rumah. Kedua, terdapatnya eksistensi Shinto, khususnya unsur persembahan (shinsen) pada kegiatan: mochitsuki, memajang kagamimochi, memajang gohei atau shide, memajang sakaki, dan melempar koin di kuil (jinja). Ketiga, terdapatnya konsep Shinto, khususnya unsur permohonan (norito) pada kegiatan: hatsumode dan norito di jinja. Keempat, terdapatnya eksistensi Shinto, khususnya unsur naorai (makan bersama di akhir perayaan) pada kegiatan makan kagamimochi yang dipotong untuk dimakan bersama setelah shogatsu selesai.

Berdasarkan data angket, kita dapat mengetahui fenomena responden terhadap pemahaman mereka pada tujuan kegiatan-kegiatan yang dilakukan pada Shogatsu. Dengan demikian, bila ingin memahami lebih dalam makna dan tujuan kegiatan yang dilakukan pada Shogatsu, kita perlu membaca hasil penelitian sebelumnya dari para ahli peneliti masyarakat dan kebudayaan Jepang, khususnya tentang Shinto.

\section{DAFTAR PUSTAKA}

Akasaka, M. (1989). Jepang Dewasa Ini. Tokyo: International Society for Educational Information.

Bonvillain, N. (2003). Language, Culture, and Communication: the Meaning of Messages. New Jersey: Prentice Hall.

Brandon, R. M., dan Barbara B.S. (1994). Spirit and Symbol the Japanese New Year. Hawaii: Honolulu Academy of Arts.

Inohana, T., dan Edizal. (2002). Mengerti Bahasa dan Budaya Jepang. Padang: Kayupsak. 
Ishizawa, T. (2006). "Pandangan Kaum Muda Terhadap Kebudayaan.“ Esai-Esai tentang Masyarakat Jepang. Diakses 16 Desember 2006, dari http://www.02.246.ne.jp/ semar/seminarunair/seminarunair.html.

Kato, G. (1971). A Study of Shinto: The Religion of the Japanese Nation. London: Curzon Press.

Ono, S. (1992). Shinto, the Kami Way. Tokyo: Charles E. Tuttle Company.

Robinson. (2006). "Shinto". Ontario Consultants on Religious Tolerance. Diakses 8 Juni 2007, dari http://www.religioustolerance.org/shinto.htm.

Sakurai, T. (1991). Understanding Japan: Japanese Beliefs. Tokyo: International Society for Educational Information, Inc.

Sudjianto. (2002). Istilah Masyarakat dan Kebudayaan Jepang. Bekasi: Kesaint Blanc.

Tsuda. (1965). Nihon Shoki. Tokyo.

. "Story of Shogatsu and 'Koh Hajime'.” Nippon Kodo. (2006). Diakses 31 Maret 2007, dari http://www.nipponkodo.com/message0501.html. 